\title{
Effects of landscape configuration on mapping ecosystem service capacity: a review of evidence and a case study in Scotland
}

\author{
Willem Verhagen • Astrid J. A. Van Teeffelen • Andrea Baggio Compagnucci • \\ Laura Poggio $\cdot$ Alessandro Gimona $\cdot$ Peter H. Verburg
}

Received: 9 October 2015 / Accepted: 4 February 2016/Published online: 23 February 2016

(C) The Author(s) 2016. This article is published with open access at Springerlink.com

\begin{abstract}
Context Humans structure landscapes for the production of food, fibre and fuel, commonly resulting in declines of non-provisioning ecosystem services (ESs). Heterogeneous landscapes are capable of providing multiple ESs, and landscape configuration-spatial arrangement of land cover in the landscape-is expected to affect ES capacity. However, the majority of ES mapping studies have not accounted for landscape configuration.

Objectives Our objective is to assess and quantify the relevance of configuration for mapping ES capacity. A review of empirical evidence for configuration effects on the capacity of ten ESs reveals that for four ESs configuration is relevant but typically ignored in ES quantification. For four ESs we quantify the
\end{abstract}

Electronic supplementary material The online version of this article (doi:10.1007/s10980-016-0345-2) contains supplementary material, which is available to authorized users.

W. Verhagen $(\bowtie) \cdot$ A. J. A. Van Teeffelen .

P. H. Verburg

Environmental Geography Group, Faculty of Earth and

Life Sciences, Vrije Universiteit Amsterdam, De

Boelelaan VU 1085, 1081HV Amsterdam, The

Netherlands

e-mail: willem.verhagen@vu.nl

A. Baggio Compagnucci · L. Poggio · A. Gimona

James Hutton Institute, Craigiebuckler,

Aberdeen AB158QH, UK relevance of configuration for mapping ESs using Scotland as a case study.

Methods Each ES was quantified through modelling, respectively ignoring or accounting for configuration. The difference in ES capacity between the two ES models was determined at multiple spatial scales.

Results Configuration affected the capacity of all four ESs mapped, particularly at the cell and watershed scale. At the scale of Scotland most local effects averaged out. Flood control and sediment retention responded strongest to configuration. ESs were affected by different aspects of configuration, thus requiring specific methods for mapping each ES.

Conclusions Accounting for configuration is important for the assessment of certain ESs at the cell and watershed scale. Incorporating configuration in landscape management provides opportunities for spatial optimization of ES capacity, but the diverging response of ESs to configuration suggests that accounting for configuration involves trade-offs between ESs.

Keywords Landscape heterogeneity - Landscape structure - Land use Land cover · Multifunctional landscapes · Trade-off · InVEST

\section{Introduction}

Many regions in the world have been transformed to large, homogeneous agricultural areas to meet increasing demands for food, fibre and fuel (Klein Goldewijk 
2001; Foley et al. 2005; Monfreda et al. 2008). The focus on providing food, fibre and fuel has often resulted in declines of non-provisioning ecosystem services (ESs) (Foley et al. 2005; Rodríguez et al. 2006; Bennett et al. 2009; Power 2010). In the upcoming decades pressures on ES capacity, the potential of an ecosystem to supply an ecosystem function or service without consideration of ES demand, are expected to grow, while demand for almost all ESs is increasing (Alcamo et al. 2005; Millenium Ecosystem Assessment 2005). Some landscapes provide high levels of a single ES. Interest in multifunctional landscapes, capable of providing multiple ESs simultaneously, is rising (Bennett et al. 2009; Jones et al. 2013; Qiu and Turner 2013; Schindler et al. 2014). A multifunctional landscape is thought to be affected by its spatial heterogeneity and can be managed through the landscape structure (Macfadyen et al. 2012; Jones et al. 2013). Unravelling the relation between ESs and landscape heterogeneity is crucial for determining the promises of multifunctional landscapes (Bennett et al. 2009; Jones et al. 2013).

Heterogeneity in land cover within and between landscapes can affect ES capacity both directly and indirectly. Heterogeneity directly affects ES capacity through ecological processes (e.g. the flow and retention of water and nutrients) or indirectly through positive effects on biodiversity (Wiens 2002; Lovett et al. 2005; Fahrig et al. 2011; Stein et al. 2014). Species richness is positively correlated to heterogeneity in land cover (Stein et al. 2014) and, although many uncertainties remain, species richness and other biodiversity indicators are positively correlated to ESs (Balvanera et al. 2006; Cardinale et al. 2012; Mace et al. 2012; Balvanera et al. 2014; Harrison et al. 2014). These direct and indirect effects suggest that the capacity of some ESs is affected by landscape heterogeneity. Landscape heterogeneity can be broken down into two components: (1) the composition, in terms of the type(s) of land cover; and (2) the configuration, the spatial arrangement of land cover types (Fahrig and Nuttle 2005; Jones et al. 2013).

The mapping of ESs is a common tool to assess ES capacity. Although many studies focus on mapping the capacity of ESs, these studies commonly do not account for landscape configuration. Mapping ES capacity is often linked to the landscape composition, using land cover proxies (Seppelt et al. 2011; Martínez-Harms and Balvanera 2012). The link between ES capacity and landscape configuration has been studied in field experiments (Liu et al. 2012; Andersson et al. 2013; Mitchell et al. 2014) but is rarely incorporated in studies mapping ESs. In studies mapping ES, the combined effects of landscape composition and configuration were incorporated by relating landscape metrics to ES values (Sherrouse et al. 2011), ecological functioning (Frank et al. 2012) and ES capacity (Laterra et al. 2012). Lautenbach et al. (2011) mapped three ESs using indicators sensitive to landscape configuration. Changes in ES capacity, following land cover change, could not be fully explained by changes in landscape composition alone, concluding that some ESs can only be quantified if indicators account for configuration as well (Lautenbach et al. 2011). Recently, Mitchell et al. (2015a) showed that fragmentation affects ESs capacity at the landscape level and at the cell level by modelling the capacity of an ES for a set of hypothetical landscapes. So far a comprehensive assessment of the relative effects of composition and configuration on a wider set of ESs is missing. The absence of studies on the relation between the components of landscape heterogeneity and ES capacity hampers landscape management for multiple ESs and fails to provide specific guidance beyond generic ideas like "heterogeneity is good" (Macfadyen et al. 2012).

The aim of this paper is to assess and quantify the importance of landscape configuration for mapping the capacity of ESs. In particular, we aim to distinguish between the effects of landscape composition and configuration on ESs in approaches to map ESs across larger regions. We start with a short overview of empirical evidence relating landscape configuration to ES capacity, focusing on studies in temperate and continental climates. Based on the evidence from field studies we account for the effect of landscape configuration on mapping ES capacity by comparing two ES models, one with and one without landscape configuration. Scotland is used as case study site.

\section{Empirical evidence for a relation between landscape configuration and ES capacity}

Review approach

To determine which ESs can be expected to be sensitive to landscape configuration, we performed a 
literature search for field studies and reviews relating landscape configuration to ES capacity. For ten commonly studied ESs with relevance to Scotland (Aspinall et al. 2011; Seppelt et al. 2011), we searched the ISI Web of Science database (timeframe: 1990May 2014), using a variety of search terms for landscape configuration, accounting for the diversity in terminology in the literature (see Supplementary material 1). For selection and reviewing of papers, we primarily focused on the relation between landscape configuration and ES capacity, but, if relevant, we also incorporated effects of landscape heterogeneity or compositional heterogeneity. Of the first 50 papers returned per combination of ES and landscape configuration term (as ranked by 'relevance' in Web of Science) we scanned title and abstract. Since we use Scotland as a case study area we focused our review on studies from temperate and continental climates. When studies from the tropics were included this is mentioned in the text. Following previous literature reviews (Harrison et al. 2014; Stein et al. 2014), the set of papers was next expanded using the snowballing technique. The snowballing technique was used because the initial set of papers primarily returned papers on general search terms, whereas papers on specific terms, such as patch size, were largely absent.

Based on the literature review we distinguished four aspects of configuration that can affect ES capacity. First, ES capacity is affected by the specific location of land cover types (e.g., Ricketts et al. 2008; Acreman and Holden 2013). Examples include discrete classes (riparian vs. non-riparian) or distance between land cover and a specific feature (e.g. roads, farms or streams). Second, ES capacity is affected by the use and structure of multiple patches (e.g., Bodin et al. 2006; Ludwig et al. 2007; Liu et al. 2012; Bateni et al. 2013), such as foraging behaviour or nutrient flows through a landscape. Third, ES capacity is affected by the structure of a single patch, such as patch size or edge effects (e.g., Forman 1995; Macfadyen and Muller 2013). Fourth, ES capacity is affected by the presence of linear elements, such as hedgerows and grass margins (e.g., Falloon et al. 2004; Pollard and Holland 2006; Borin et al. 2010). We included linear elements, because of their effect on the spatial patterning of land cover and their expected importance for a subset of ESs. Below we summarize the main results from the literature review.
Review results

There is evidence for an effect of configuration on ES capacity for four ESs, namely nutrient retention, pollination, landscape aesthetics and sediment retention (Table 1). The evidence for an effect of configuration on crop production, flood control and pest control is mixed. No evidence is found for a relation between landscape configuration and carbon sequestration. Our literature search did not yield studies on the relation between landscape configuration and wood production or cattle farming. We first discuss the ESs for which there is no or mixed evidence, followed by ESs affected by landscape configuration.

No evidence is found for a relation between landscape configuration and carbon sequestration. Soil organic carbon shows no difference along a gradient of landscape heterogeneity (Williams and Hedlund 2013) and hedgerows only locally increase soil organic carbon (D'Acunto et al. 2014). In tropical systems forest fragmentation and edge effects result in a decrease in carbon sequestration (de Paula et al. 2011; Laurance et al. 2011) but preliminary evidence suggests that in temperate regions carbon sequestration is unaffected in forest edges (Ziter et al. 2014).

Crop production is affected by configuration but these effects are often indirect, due to time lags or ES interactions. In the UK, returns from crop production are reduced, but show less annual variation in landscapes with a higher diversity of agricultural land uses (Abson et al. 2013). Increases in crop production in France-following the disappearance of seminatural habitat and linear elements-decline with increasing dependency of the crop on pollination (Deguines et al. 2014). Crop production is reduced at field edges, especially when the field edge is adjacent to tree lines or hedges (Sparkes et al. 1998; Foereid et al. 2002), but in general effects are considered to be local and small compared to total crop production (Borin et al. 2010).

Pest control constitutes of the interaction between pest species and natural enemies. A review and metaanalysis of pest control studies both show that natural enemy populations respond positively to increasing landscape complexity (Bianchi et al. 2006; ChaplinKramer et al. 2011). An increase in natural enemy populations does not necessarily translate into increased pest control, because pest species populations can also respond positively to increasing 
Table 1 Overview of empirical evidence for the dependency of ES capacity on configuration. When evidence exists for a relation between ES capacity and configuration, the type of configuration effect(s) are specified (ï). Individual letters

\begin{tabular}{ll}
\hline $\begin{array}{l}\text { Ecosystem } \\
\text { service }\end{array}$ & $\begin{array}{l}\text { No papers/no } \\
\text { effect }\end{array}$ \\
\hline $\begin{array}{l}\text { Carbon } \\
\text { sequestration }\end{array}$ & \\
Cattle production & No papers \\
Crop production $^{\mathrm{b}}$ & \\
Flood control $^{\mathrm{c}}$ & \\
Nutrient $^{\text {retention }}{ }^{\mathrm{d}}$ & \\
Pest control $^{\mathrm{e}}$ & \\
Pollination $^{\mathrm{f}}$ & \\
Landscape $^{\text {aesthetics }}{ }^{\mathrm{g}}$ & \\
Sediment $^{\mathrm{r}}$ & \\
retention $^{\mathrm{h}}$ & \\
Wood production & No papers
\end{tabular}

correspond to the key references that substantiate the individual claims per ES (see footnote). For cattle and wood production the search term did not return any papers on the relation to landscape heterogeneity

\footnotetext{
${ }^{a}$ Falloon et al. (2004), Follain et al. (2007), Borin et al. (2010), Laurance et al. (2011), de Paula et al. (2011), Lenka et al. (2012), Williams and Hedlund (2013), D'Acunto et al. (2014), Ziter et al. (2014)

b Sparkes et al. (1998), Foereid et al. (2002), Roschewitz et al. (2005b), Borin et al. (2010), Persson et al. (2010), Poveda et al. (2012), Abson et al. (2013), Lemessa et al. (2013), Deguines et al. (2014)

c Carroll et al. (2004), Calder (2007), Marshall et al. (2009), Borin et al. (2010), Mayor et al. (2011), Sriwongsitanon and Taesombat (2011), Lenka et al. (2012), Acreman and Holden (2013), von Freyberg et al. (2014)

${ }^{d}$ Castelle et al. (1994), Johnson et al. (1997), Heathwaite et al. (1998), Braskerud (2002), Gergel (2005), Wang et al. (2005), Uuemaa et al. (2005), Lee et al. (2009), Borin et al. (2010), Liu et al. (2012), Sun et al. (2013), Bateni et al. (2013)

e Thies and Tscharntke (1999), Roschewitz et al. (2005a), Bianchi et al. (2006), Pollard and Holland (2006), Tscharntke et al. (2007), Vollhardt et al. (2008), Perović et al. (2010), Bianchi et al. (2010), Chaplin-Kramer et al. (2011), Rusch et al. (2012), Poveda et al. (2012), Chaplin-Kramer and Kremen (2012), Pisani et al. (2013), Macfadyen and Muller (2013), Veres et al. (2013), Bianchi et al. (2013), Martin et al. (2013), Rusch et al. (2013), Mitchell et al. (2014), Morandin et al. (2014)

${ }^{\mathrm{f}}$ Svensson et al. (2000), Kells et al. (2001), Potts et al. (2003), Kremen et al. (2004), Bodin et al. (2006), Williams and Kremen (2007), Ricketts et al. (2008), Winfree et al. (2009), Isaacs and Kirk (2010), Kennedy et al. (2013), Morandin and Kremen (2013), Rollin et al. (2013), Bailey et al. (2014), Stanley and Stout (2014)

g de la Fuente de Val et al. (2006), Dramstad et al. (2006), Borin et al. (2010), Kienast et al. (2012), van Zanten et al. (2014)

h Castelle et al. (1994), Bartley et al. (2006), Ludwig et al. (2007), Bu et al. (2008), Lenka et al. (2012), Yang et al. (2012), Shi et al. (2013)
}

landscape complexity (Bianchi et al. 2006; ChaplinKramer et al. 2011). The same issue applies to studies on linear elements and pest control, although Morandin et al. (2014) show that fields adjacent to hedgerows less frequently reach pest pressure levels that require insecticides use.

For flood control there is evidence for an effect of configuration on ES capacity. The location of land cover affects runoff. For example, the percentage of rainfall that resulted in runoff decreased with increasing upstream area, attributed to infiltration of runoff along the flow path (Mayor et al. 2011). Linear elements can greatly reduce runoff (Borin et al. 2010) and in the UK the presence of individual trees and shelterbelts increases the infiltration capacity of grazed pastures (Marshall et al. 2009). The effect of land cover depends however on the amount of rainfall and diminishes with increasing soil saturation (Lull 
and Reinhart 1972; Calder 2007; Acreman and Holden 2013). In mountainous catchments the riparian zone dominates the runoff response and intercepts high amounts of nutrients but also contributes most to runoff during conditions of high soil saturation (von Freyberg et al. 2014). Forests can store large amounts of water but during larger rainfall events forest areas in the tropics produce more runoff than non-forested areas because of quick soil saturation and increased base flow (Sriwongsitanon and Taesombat 2011).

There is evidence for a relation between landscape configuration and the ESs nutrient retention, sediment retention, pollination and landscape aesthetics. Each ES is however affected by different aspects of landscape configuration (Table 1). Sediment retention and nutrient retention, here limited to nitrogen, respond largely similar to configuration. Retention services are affected by the location of land cover, especially riparian vegetation (Castelle et al. 1994; Johnson et al. 1997) and the structure of multiple patches, both at landscape scale (Liu et al. 2012; Bateni et al. 2013) and at the hillslope scale in the tropics (Bartley et al. 2006; Ludwig et al. 2007). Buffer strips and wetlands can intercept high amounts of nutrients and sediment (Castelle et al. 1994; Heathwaite et al. 1998).

Pollination, here limited to pollination by wild bees, is affected by all aspects of landscape configuration. Pollination capacity is affected by the location of land cover types. Abundance and visitation rates of bees to cropland strongly decrease with increasing distance between cropland and bee habitat (Ricketts et al. 2008). Moreover, pollination capacity is affected by the structure of multiple and single patches. Bees require both nesting sites and floral resources in close proximity (Potts et al. 2003; Williams and Kremen 2007). Forest edges typically harbour more nesting opportunities and floral resources than interior forest sites (Svensson et al. 2000; Kells and Goulson 2003). Last, linear elements can provide important habitat for bee species and reduce flight distances. Stanley and Stout (2014) found large overlap between pollinators visiting oil seed rape crops and wild flowers in hedgerows, even during mass flowering of the crops, suggesting that hedgerows can be an important additional floral resource.

Landscape aesthetics, here a combination of recreation potential and landscape aesthetics, is influenced by the structure of multiple patches. Several studies stress the importance of compositional and configurational heterogeneity for recreation (de la Fuente de Val et al. 2006; Dramstad et al. 2006; Kienast et al. 2012). Moreover, a metaanalysis on landscape preferences showed that a mosaic landscape is more appreciated than either an agricultural or natural dominated landscape (van Zanten et al. 2014). The presence of linear elements resulted in a wide variety of responses in landscape preferences, making generalization difficult (van Zanten et al. 2014).

\section{Comparison to ES mapping studies}

We performed a review of ES mapping studies to determine whether these studies account for configuration. Studies mapping ES capacity were selected from a database of $271 \mathrm{ES}$ case studies published until 1.8.2013 (Seppelt et al. 2011, and extended by Lautenbach et al. 2015). Of the 271 papers in the database, 73 studies mapped ES. We incorporated studies mapping nutrient and sediment retention, landscape aesthetics and pollination. Furthermore, we included studies mapping flood control because configuration affects flood control under certain conditions. Per mapping study we checked whether the study accounted for configuration in mapping the ESs and which of the four aspects of configuration were incorporated. The majority of ES mapping studies $(65 \%)$ does not account for configuration in mapping ES capacity (Table 2). Studies that account for configuration do not always account for all aspects of configuration. None of the studies mapping landscape aesthetics capacity account for configuration. Only for nutrient retention the majority of studies (73\%) accounts for configuration. For nutrient and sediment retention, studies that account for configuration commonly use the InVEST model (Kareiva et al. 2011). Linear elements are never incorporated in the assessment. Based on the findings from the two literature reviews we conclude that there is a potential gap in accounting for configuration for mapping the ES capacity of flood control, sediment retention, landscape aesthetics and pollination. 
Table 2 Number of ecosystem service mapping studies that account for configuration in the indicators used, and the type of configuration effect that is accounted for. The total number of studies that account for configuration per ecosystem service

\begin{tabular}{|c|c|c|c|c|c|c|}
\hline \multirow[t]{2}{*}{ Ecosystem services } & \multirow[t]{2}{*}{ \# of studies } & \multirow[t]{2}{*}{ No effect } & \multicolumn{4}{|c|}{ Accounts for effect of } \\
\hline & & & $\begin{array}{l}\text { Location of } \\
\text { land cover }\end{array}$ & $\begin{array}{l}\text { Multiple } \\
\text { patches }\end{array}$ & $\begin{array}{l}\text { Single } \\
\text { patch }\end{array}$ & $\begin{array}{l}\text { Landscape } \\
\text { elements }\end{array}$ \\
\hline Flood control & 5 & 4 & 1 & & & 0 \\
\hline Nutrient retention & 6 & 2 & 4 & 3 & & 0 \\
\hline Pollination & 3 & 2 & 1 & 1 & 0 & 0 \\
\hline Landscape aesthetics & 6 & 6 & & 0 & & \\
\hline Sediment retention & 11 & 8 & 3 & 2 & & 0 \\
\hline
\end{tabular}

does not have to equal the type of configuration effects incorporated, because a single study can account for multiple configuration effects. No effect indicates that the ES mapping study does not account for configuration

\section{Quantifying the effect of configuration for ES mapping: methods}

\section{Mapping ES capacity}

Following the results of the literature review we quantified and mapped the capacity of four ESs for Scotland: flood control, sediment retention, landscape aesthetics and pollination. Nutrient retention was omitted because configuration affects nutrient retention and sediment retention in a similar way (Table 1) and the majority of studies mapping nutrient retention accounted for configuration (Table 2). Per ES, the capacity was modelled using two different modelling approaches, which were compared to understand the effect of accounting for configuration in ES quantification and mapping. First, ES capacity was quantified based on landscape composition only (referred to as "composition model" hereafter), and second, ES capacity was quantified based on both landscape composition and configuration (referred to as "configuration model" hereafter). All ES models were, where possible, based on existing modelling approaches and were kept as simple as possible to distil the configuration effect. Land cover was obtained from the 2007 UK land cover map ( $1 \mathrm{~cm} 2007)$ raster version at $25 \mathrm{~m}$ resolution (referred to as "cell" hereafter) (CEH 2011).

The composition models for all ESs were largely based on land cover proxies: each cell was assigned a single value per ES, based on its land cover. Land cover proxies do not account for configuration, i.e. the projected ES capacity is always the same for a cell of a
Accounts for effect of

given land cover type, irrespective of landscape configuration (Burkhard et al. 2009). In other words, the ES land cover proxies balance all possible landscape configurations and ultimately represent the on-average effect of landscape configuration. In all models, we assumed that the composition model represents the ES capacity based on the landscape composition and the average configuration effect. Hence, the larger the deviations of the configuration model from the composition model, the larger the effect of accounting for configuration on ES capacity. Following this rationale, accounting for landscape configuration can increase or decrease a cell's ES capacity, as projected by the composition model. We refer to an increase (decrease) as a positive (negative) effect of landscape configuration on ES capacity. Per model we explain the calculation of the average configuration effect below. Detailed descriptions of all composition and configuration models are provided in Supplementary material 2.

\section{Sediment retention capacity}

Sediment retention capacity was mapped using InVEST (Kareiva et al. 2011). The InVEST model has been extensively documented (Kareiva et al. 2011), but a short summary of the main components is included here. In the InVEST model, sediment retention consists of (i) sediment retention at the cell and (ii) filtration of sediment input from upstream cells. Sediment retention at the cell was calculated using the revised universal soil loss equation (Renard et al. 1997), based on rainfall, soil erodibility, topography, 
the land cover and the land management. Sediment retention at the cell is calculated as the difference in soil loss of a cell with and without accounting for the effect of the cell's land cover. Sediment filtration was calculated based on a land cover proxy and the sediment input from upstream cells. The land cover proxy for filtration was assigned to each land cover type based on a combination of literature (May and Place 2005; Anderson et al. 2010; Sude et al. 2011), documentation of the InVEST model and an expert assessment. Sediment input depends on the position of the cell in the landscape and the land cover of surrounding cells. Per watershed in Scotland we calculated the average sediment input of all cells in the watershed. In the composition model, all cells within a watershed were assigned this average sediment input value. In the configuration model, sediment filtration per cell was calculated using the actual sediment input per cell.

\section{Flood control capacity}

In the composition model, flood control capacity was quantified using land cover proxies for flood protection from Burkhard et al. (2012). Burkhard et al. (2012) assigned a value (0-5) per ES to each CORINE land cover type, based on field studies and expert assessment. The values from the ES matrix were divided by five to range from 0 to 1 , as has been done by others before (Schulp et al. 2014a; Stoll et al. 2014). As we used $1 \mathrm{~cm} 2007$ land cover data, we transferred the land cover proxies per CORINE land cover class to the closest lcm2007 class (Supplementary material 1). In the configuration model, flood control capacity of a cell depended on the land cover of that cell (composition model) and on the location of the cell along the flow path. Following Chan et al. (2006), we calculated the flow accumulation value (FACC) per cell as the number of upstream cells, irrespective of land cover type, potentially transporting water into a single cell. The FACC accounts for the position of the cell within a watershed relative to the flow path. Per watershed we calculated the average FACC value of all cells in the watershed. The FACC value of a cell was scaled relative to the average FACC of the watershed to which the cell belonged, indicating that cells with a high amount of upstream area contribute more to flood control. Modelled effects of landscape composition and configuration do not apply under conditions of full soil saturation.

\section{Landscape aesthetic capacity}

In the composition model landscape aesthetic capacity was quantified using land cover proxies for "landscape aesthetics and inspiration" from Burkhard et al. (2014). As for flood control, we transferred the land cover proxies per CORINE land cover to the closest lcm2007 land cover. In the configuration model, landscape aesthetics capacity depended on the land cover proxy (composition model) and the surrounding land cover diversity. Land cover diversity assigned to a cell was determined by two factors: the landscape type surrounding a cell, and the land cover diversity within that landscape type. First, we assigned each cell to one of three generic landscape types: natural dominated landscape, agricultural dominated landscape or mosaic landscape. The landscape type was calculated within a view shed of $200 \mathrm{~m}$ following Casado-Arzuaga et al. (2013). Agricultural dominated landscapes had $>50 \%$ agricultural land cover in the view shed, whereas natural dominated landscapes had $>50 \%$ natural land cover in the view shed. In mosaic landscapes none of the two land covers, agriculture or natural, dominated. We obtained landscape preference scores per landscape type from a meta-analysis for European agricultural landscapes (van Zanten et al. 2014). The landscape preferences were in the order mosaic (most preferred), natural, agricultural (least preferred) (van Zanten et al. 2014). Each cell was assigned a landscape preference score based on the landscape type it belonged to. Second, we calculated the Shannon diversity index (SHDI) per cell based on land cover, again within a view shed of $200 \mathrm{~m}$. Third, per cell, we calculated the overall land cover diversity score by normalizing (min-max normalization) the SHDI value using the landscape preferences for the generic landscape type of that cell (minimum) and mosaic landscapes (maximum). Fourth and last, the overall land cover diversity score per cell was scaled relative to the average land cover diversity score for Scotland. The landscape preference scores from the meta-analysis by van Zanten et al. (2014) apply to European agricultural landscapes. Due to a lack of other data sources on the effect of land cover diversity 
on landscape aesthetics potential, we applied the same methodology to all landscapes in Scotland.

\section{Pollination capacity}

Pollination capacity per cell was quantified with land cover proxies from Zulian et al. (2013), who present separate land cover proxies for nesting suitability and floral resource availability for bees per CORINE land cover type. In the composition model, pollination capacity was mapped using the nesting suitability scores. Following Lautenbach et al. (2011), nesting suitability values for wild bees were not assigned to cropland. As for landscape aesthetics and flood control, we transferred the land cover proxies per CORINE land cover to the closest $1 \mathrm{~cm} 2007$ land cover. In the configuration model, pollination capacity was quantified using the InVEST pollination model (Lonsdorf et al. 2011). In InVEST, pollination capacity of a cell depends on the nesting suitability of a cell, floral resource availability within the surroundings of nesting cells, and the distance between nesting cells and cropland. Land cover proxies for floral resource availability were obtained from Zulian et al. (2013). Compared to the InVEST model, three adjustments were made. First, following Zulian et al. (2013) we accounted for edge effects by assigning separate values for nesting suitability and floral resource availability to forest interior and edge cells. Forest edge cells were defined as those cells within $50 \mathrm{~m}$ from other land cover types. Second, in InVEST the effect of floral resource availability on pollination capacity declines with distance (Lonsdorf et al. 2011). We applied a maximum bee flight distance of $500 \mathrm{~m}$ following Lautenbach et al. (2011). Per cell, we additionally calculated the average floral resource availability within a 500-m radius from the nesting cell without accounting for distance decay or edge effects. We adjusted the InVEST model by scaling the floral resource availability per nesting cell, after accounting for distance decay and edge effects, relative to the average floral resource availability. Third, in InVEST pollination capacity of a site declined with increasing distance from cropland cells (Lonsdorf et al. 2011). In contrast to InVEST, we assigned pollination capacity scores to the nesting cells and not to cropland cells. Furthermore, we calculated the average distance decay effect for distance to cropland, again using a 500-m radius. If the $500 \mathrm{~m}$ radius would be split at $353.55 \mathrm{~m}$, the area of the inner and outer circle would be equal and both circles could potentially hold the same amount of cropland cells. The average distance decay effect is therefore calculated as the distance decay effect at $353.55 \mathrm{~m}$. The effect of distance to cropland per cell was scaled relative to the average distance decay effect. In both the composition and configuration model, pollination capacity was only assigned to nesting sites within $500 \mathrm{~m}$ of cropland.

Comparing ES composition and configuration models

We compared the ES composition and configuration models to assess the effect of accounting for configuration on the level of ES capacity and the spatial pattern of ES capacity across scales. First, we calculated the effect of accounting for configuration on mapping ES capacity per cell as the difference in the ES capacity between the configuration and composition model divided by the ES capacity of the composition model (referred to as "relative effect"). A positive (negative) relative effect of configuration means that accounting for configuration increases (decreases) the ES capacity. Second, we mapped the percentage difference per cell to assess spatial patterns across Scotland and within a single watershed. The percentage difference is simply the relative effect multiplied by $100 \%$. Third, we calculated the average of the absolute percentage difference in ES capacity for all cells, all watersheds, and for Scotland as a whole. The last analysis accounts for the absolute effect of configuration across scales and does not account for positive and negative effects of configuration on mapping ES capacity.

Next to the comparison of the ES models we tested whether the percentage difference between the composition and configuration model per cell could be approximated using landscape metrics. We calculated the correlation between three landscape metrics and the difference in ES capacity using Pearson's correlation coefficients. A high correlation would indicate that a particular landscape metric could be used to account for the effect of configuration on mapping that ES. We selected three landscape metrics: a landscape 
Table 3 Percentage mean absolute difference and standard deviation between total ES capacity for the composition and configuration model per ES. Results are presented at the national level, at the watershed level and at the cell level. Min-max present the minimum and maximum percentage difference for all watersheds or cells. A negative minimum value means that accounting for configuration results in a decrease in ES capacity for that watershed or cell
Fig. 1 Boxplots showing the relative effect of configuration to ES capacity at the cell level. All effects are scaled relative to the ES capacity value for the composition model (0 line). A value of 0.0 means that the outcomes of the composition and configuration model are equal, whereas a value of 0.2 means that accounting for configuration results in a $20 \%$ increase in ES capacity, and vice versa. The solid black line in each boxplot represents the median effect. Outliers are not depicted. Boxplots, including the outliers are depicted in Supplementary material 1

\begin{tabular}{lccc}
\hline & $\begin{array}{c}\text { Mean absolute } \\
\text { difference }(\%)\end{array}$ & SD (\%) & Min-max (\%) \\
\hline $\begin{array}{l}\text { Flood control } \\
\text { National }\end{array}$ & 0.58 & & \\
Watershed & 6.18 & 9.34 & -82.67 to 296.65 \\
Cell & 122.8 & 13.8 & -98.66 to 747.75 \\
Pollination & 2.61 & & \\
National & 6.59 & 11.75 & -83.01 to 22.92 \\
Watershed & 13.8 & 11.8 & -86.94 to 339.66 \\
Cell & & & -22.41 to 16.23 \\
Landscape aesthetics & 1.49 & & -22.60 to 36.44 \\
National & 3.41 & 2.81 & \\
Watershed & 7.68 & 5.33 & -59.16 to 35.05 \\
Cell & & & -100.0 to 106.34 \\
Sediment retention & 5.62 & 5.59 & \\
National & 2.61 & 90.65 & \\
Watershed & 49.9 & & \\
Cell & & & \\
\hline
\end{tabular}



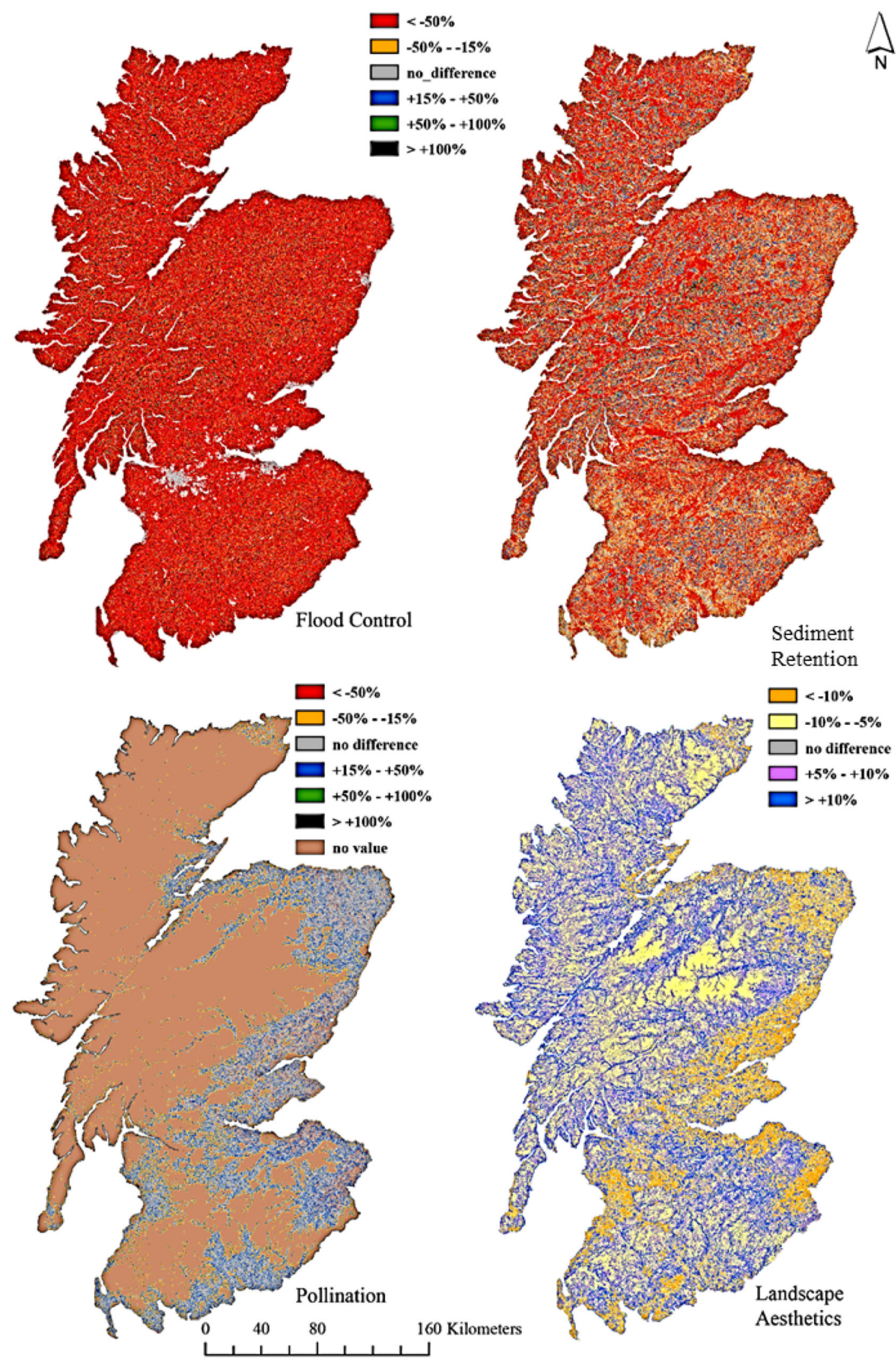

黛 Springer 
4Fig. 2 Percentage difference between the composition and configuration model per cell for Scotland. A percentage decrease means that accounting for configuration results in an decrease in ES capacity, and vice versa. The maps only depict the result for mainland Scotland, excluding all islands. For flood control, urban areas were assigned a value of zero for flood control potential in the composition model, resulting in no difference between the composition and configuration models (areas in grey). For pollination, there are many cells with "no value" as we did not assign values for pollination potential for cropland cells and for habitat cells further than $500 \mathrm{~m}$ away from cropland

composition metric (\% natural vegetation), a compositional heterogeneity metric (land cover richness) and a landscape configuration metric (patch density). Patches were identified as cells of identical land cover within an eight cell neighbourhood. Patch density equalled the total number of patches in an area (summed over all land cover types). According to results from our literature review, the structure of multiple patches, including patch density, was related to sediment retention, pollination and landscape aesthetics. A preliminary analysis showed that patch density is highly correlated with edge density. Previous research showed that edge density is a good predictor of sediment retention (Uuemaa et al. 2005; Liu et al. 2012). Correlations with many more landscape metrics could have been tested, but we decided to only select three metrics that are readily explained, and hence can serve to draft hypotheses on the relation between configuration and ES capacity. For the services flood control and sediment retention we additionally calculated the distance per cell to the closest stream or river per watershed ("distance to water"). The correlations were calculated for a sample of the data to reduce potential bias from spatial autocorrelation. We sampled $10 \%$ of all cells with a minimum distance of $100 \mathrm{~m}$ between each cell. For pollination, a separate sample was taken only from the nesting sites within $500 \mathrm{~m}$ of cropland. Per cell, the landscape metrics were calculated on the land cover within 250,500 and $1000 \mathrm{~m}$ radii to assess the sensitivity of the correlation for the selected radii. All statistical analysis were conducted in R (R Core Team 2013) including the additional packages 'bigmemory' (Kane et al. 2013) and 'reshape'(Wickham 2007).

\section{Results}

Difference between the ES composition and configuration models

For all four ES mapped here, incorporating landscape configuration changes ES capacity compared to incorporating landscape composition alone. The ES capacity of all ESs differs between the composition and the configuration model although the effect depends on the level of aggregation (national, watershed and cell). Differences between the composition and configuration model are largest at the cell scale (Table 3). At the cell scale, flood control is affected most strongly by configuration, followed by sediment retention and pollination. Accounting for configuration does not have a strong effect on landscape aesthetics at the cell level. At the watershed scale differences between the composition and configuration model are smaller on average, but certain watersheds show large differences. Especially watersheds with little remaining natural vegetation are very sensitive to the spatial arrangement of natural vegetation. At the watershed scale, pollination is affected most strongly by configuration followed by flood control. Accounting for configuration has a small effect on ES capacity of sediment retention and landscape aesthetics. At the national scale differences between the composition and configuration models for ES capacity are small for all ESs (Table 3). In general, accounting for configuration makes substantial difference on the level of ES capacity at the cell scale and at the watershed scale. For the whole of Scotland local effects of configuration average out and in general hardly affect the ES capacity.

At the cell scale, the relative effect of configuration on ES capacity differs per ES (Fig. 1). The relative effect of configuration to ES capacity shows a large range per ES, being both positive and negative for all ESs depending on location. Positive values indicate that the configuration model projects a higher ES capacity than the composition model for a given cell. Negative values indicate the opposite: the configuration model projects lower values of ES capacity than the composition model. There are some clear differences between ESs in the relative effect of 

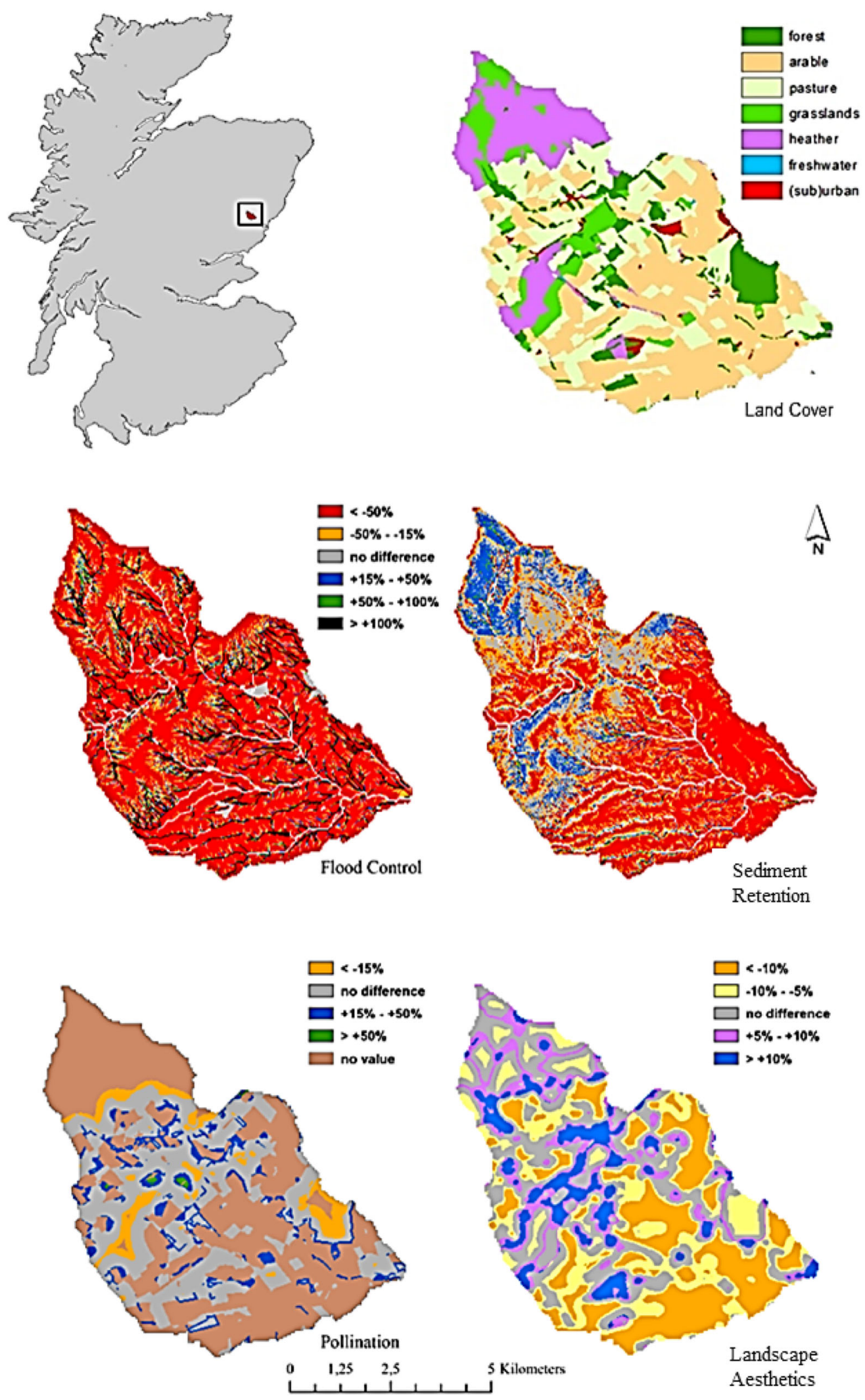
4Fig. 3 Percentage difference between the composition and configuration model per cell within a watershed. A percentage decrease means that accounting for configuration results in an decrease in ES capacity, and vice versa. For pollination, there are many cells with "no value" as we did not assign values for pollination potential for cropland cells and for habitat cells further than $500 \mathrm{~m}$ away from cropland. This particular watershed was selected because it represents a gradient in dominant land cover type from natural dominated land cover in the north to agricultural dominated land cover in the south. We merged some land cover classification categories in the top left figure for illustrational purposes

composition and configuration to ES capacity. For sediment retention and flood control, the relative effect of configuration is often larger and negative, resulting in a decrease in the mapped ES capacity. For pollination and landscape aesthetics, the relative contribution of configuration is often smaller and the contribution to ES capacity is evenly distributed between positive and negative effects. To conclude, accounting for configuration is likely to have a larger effect on mapping the ES capacity for flood control and sediment retention compared to pollination and landscape aesthetics at the cell scale. For most cells accounting for configuration will reduce the mapped ES capacity for flood control and sediment retention for the majority of cells.

\section{Spatial pattern of differences between composition} and configuration models

The differences between the composition and configuration models differs per location for all ESs but only shows a spatial pattern for landscape aesthetics for the whole of Scotland (Fig. 2). Landscape aesthetics capacity decreases in areas with homogeneous land cover, being either agricultural-dominated or having large areas of natural land cover. Landscape aesthetics capacity increases at the edges of the agricultural areas, where the landscape aesthetics capacity of both agricultural and natural land cover is positively influenced by the diversity of land cover types in close proximity. For example, cropland areas are mainly located along the eastern shore of Scotland where large areas show a decrease in ES capacity. At the edge of these cropland areas landscape aesthetics capacity increases because of a mix of natural and artificial land cover types.

To illustrate the effect of configuration at smaller spatial scales we mapped the difference between the composition and configuration model within a single watershed (Fig. 3). This particular watershed was selected because it has a gradient in dominant land cover type from dominant natural land cover in the northern part to dominant agricultural land cover in the southern part, and a mix of agricultural and natural land cover in the central part. Within this watershed the differences between the composition and configuration models show a spatial pattern for all ESs, resulting in areas with a predominant increase or decrease in ES capacity. The resulting spatial pattern differs per ESs. For flood control, the spatial pattern is similar throughout the watershed. Flood control capacity increases strongly along flow paths and closer to water courses, whereas it decreases in most cells located further away from water courses. For sediment retention, the spatial pattern of the differences between the ES models is dependent on the dominant land cover type. In areas dominated by agricultural land cover sediment retention capacity primarily decreases, while it increases for land cover adjacent to streams and rivers. Agricultural land cover has a low filtration capacity resulting in sediment accumulation towards the stream. In areas dominated by natural vegetation sediment retention capacity mostly increases, while it decreases for land cover closest and furthest away from streams and rivers. Many natural land cover types have a high filtration capacity meaning that most sediment is intercepted close to the source and there is no sediment accumulation towards the stream. Pollination capacity is only assessed for natural land cover in the agriculturaldominated area, because of the maximum distance of $500 \mathrm{~m}$ between cropland and nesting sites. Pollination capacity predominantly shows little difference between the composition and configuration model. Increased pollination capacity is observed for smaller habitat patches and for edge habitats, whereas decreased pollination capacity is observed in the interior of larger habitat patches. Landscape aesthetics show a similar spatial pattern of the differences between the composition and configuration model within a watershed as at the national scale.

Landscape metrics and the difference between the composition and configuration model

Correlations between landscape metrics and the difference between the composition and configuration 
Table 4 Pearson correlation coefficients for a set of landscape metrics and the difference between the composition and configuration model per ES

\begin{tabular}{|c|c|c|c|c|c|}
\hline & Radius (m) & Pollination & Landscape aesthetics & Sediment retention & Flood control \\
\hline \multirow[t]{3}{*}{$\%$ natural vegetation } & 250 & 0.05 & $0.36^{*}$ & $-0.01 *$ & $-0.01 *$ \\
\hline & 500 & -0.01 & $0.33 *$ & $-0.01 *$ & $-0.01 *$ \\
\hline & 1000 & -0.06 & $0.28 *$ & 0.00 & $-0.01 *$ \\
\hline \multirow[t]{3}{*}{ LC richness } & 250 & $0.32 *$ & $0.74 *$ & $0.02 *$ & $0.03 *$ \\
\hline & 500 & $0.32 *$ & $0.34 *$ & 0.00 & $0.01 *$ \\
\hline & 1000 & 0.01 & $0.54 *$ & $0.01 *$ & $0.02 *$ \\
\hline \multirow[t]{3}{*}{ Patch density } & 250 & $0.29 *$ & $0.72 *$ & $0.02 *$ & $0.03^{*}$ \\
\hline & 500 & $0.26 *$ & $0.54 *$ & $0.01 *$ & $0.02 *$ \\
\hline & 1000 & 0.04 & $0.36^{*}$ & 0.00 & $0.01 *$ \\
\hline Distance to water & & & & $-0.03 *$ & $-0.1^{*}$ \\
\hline
\end{tabular}

Landscape metrics were calculated for land cover within three radii around a cell (250, 500 and $1000 \mathrm{~m})$. For flood control and sediment retention the correlation is also calculated for the distance from the cell to the nearest stream or river in each watershed. All correlations, indicate by $*$, are statistically significant $(\mathrm{p} \leq 0.05)$

model range from the absence of any correlation at all radii for flood control and sediment retention to moderate correlations for pollination and landscape aesthetics (Table 4). Landscape aesthetics shows a relatively high correlation with "patch density" and "land cover richness", especially at $250 \mathrm{~m}$ radius. This correlation decreases with increasing radii. Pollination shows a correlation with "patch density" and "land cover richness" up to $500 \mathrm{~m}$. Flood control and sediment retention show no correlation with landscape metrics. "Distance to water", as a simple proxy for the flow accumulation, shows low correlation with flood control and no correlation with sediment retention.

\section{Discussion}

Landscape configuration and ESs in field studies

We started our analysis by reviewing the empirical evidence for a relation between landscape configuration and ten ESs. We found evidence for a relation between landscape configuration and nutrient retention, pollination, landscape aesthetics and sediment retention. Moreover, there is evidence for a relation between landscape configuration and flood control, for unsaturated soils. The results from the review are likely to be applicable outside Scotland because our review incorporated studies from sites in temperate and continental climates. Mitchell et al. (2013) performed a review on landscape connectivity and ESs, highlighting that there is a lack of empirical studies on the relation between landscape connectivity and ESs and only finding a clear relation between landscape connectivity and pollination. In line with the findings from Mitchell et al. (2013) we conclude that the number of studies that assess the relationships between landscape configuration and ESs remains limited and that empirical evidence for the relationship remains scarce. In contrast to their review we found evidence for a relation between landscape configuration and pollination as well as for four additional ESs. In our review we included a broader definition of configuration effects in relation to ES capacity and we included studies from outside the ES community, which could explain the difference between the two reviews.

Our review also highlighted that different aspects of configuration affect ES capacity. In a recent conceptual paper, Mitchell et al. (2015a, b) identified four possible ways in which landscape fragmentation affects ES capacity, namely increased interspersion of land cover, increased isolation, reduced patch size and increased edges. The first three aspects of the framework by Mitchell et al. (2015a, b) would in our classification be grouped together under "configuration of multiple patches" and are expected to have an effect on pollination, landscape aesthetics, erosion control and nutrient retention. The fourth aspect, an 
increased amount of forest edges is according to our review expected to affect pollination. In addition to the framework suggested by Mitchell et al. $(2015 a, b)$ we incorporated the specific location of land cover that affects flood control and linear elements that affect pollination, erosion control and nutrient retention.

\section{Consequences for mapping ES capacity}

Models and indicators for mapping ESs do not commonly account for configuration. Our results suggest that for particular ESs, when quantified at the watershed or cell scale, it is important to account for configuration. The effect of accounting for configuration changes with the resolution of the analysis. This has important consequences for mapping ESs. ES assessments interested in the quantification of the level of ES capacity at large, national, scales do not have to account for configuration effects as local effects of configuration largely average out. Although the total ES capacity at the national scale is hardly affected configuration does change the locations with higher and lower ES capacity at the national scale. At the watershed and cell scale, accounting for configuration can affect the level of ES capacity. Only for landscape aesthetics accounting for configuration had a small effect on the level of ES capacity at all scales.

For a hypothetical landscape, Mitchell et al. (2015a) showed that landscape fragmentation effects on ESs are non-linear from the cell to the landscape scale. The notion that the effects of configuration on ESs are scale dependent (Fahrig et al. 2011; Mitchell et al. 2015a), is confirmed by our results. In our models, configuration had a different effect on mapping ESs at the cell and the watershed scale. Flood control and sediment retention were strongly affected by configuration at the cell scale. Pollination was less strongly affected by configuration at the cell scale but accounting for configuration at the watershed scale had the strongest effect on pollination. For sediment retention local negative and positive effects of configuration tended to average out at the watershed scale. Mapping of flood control was still affected by configuration at the watershed scale. Our review highlighted that landscape configuration shapes erosion and runoff processes at the scale of individual hillslopes and watersheds. Assessment tools have been developed that can account for the different erosion and runoff processes at hillslope and watershed scale which could be implemented in ES mapping studies (Goodrich et al. 2011).

Accounting for configuration in ES mapping can partly address issues raised by previous researchers on mapping ESs using solely landscape composition. In the UK, Eigenbrod et al. (2010) showed that using landscape composition models to map ESs resulted in a mismatch with primary data on ESs. This mismatch is attributed to three types of generalization errors (Plummer 2009), of which the uniformity error can be accounted for by configuration. The uniformity error is associated with the assumption that a land cover type supplies the same amount of ES capacity irrespective of for example patch size, management history or location in the landscape. ES mapping that accounts for configuration can incorporate effects of patch size and location in the landscape, and could thus partly address the uniformity error.

We tested whether certain commonly-used landscape metrics can be used to proxy the configuration effect in mapping ESs. Only for landscape aesthetics, we found a correlation between the change in modelled ES capacity and the landscape metrics "land cover richness" and "patch density". The correlation diminished with increasing radii over which the landscape metrics were calculated. Care should be taken in interpretation and generalization of this result. For land cover richness the high correlation may be explained by the use of SHDI to account for land cover diversity in our configuration model. Moreover, at $250 \mathrm{~m}$ radius "land cover richness" and "patch density" are highly correlated (0.95). Lastly, the correlation is likely highest at $250 \mathrm{~m}$ radius, because we used a constant view shed of $200 \mathrm{~m}$ in the model. Spatial autocorrelation in the landscape metrics can contribute to the correlations found at larger resolutions. Nonetheless the correlation between the two landscape metrics and the difference between the composition and configuration model for landscape aesthetics capacity is high, irrespective of the dominant land cover type. Our findings are in line with previous research finding opportunities to assess landscape aesthetics using SHDI and patch density for landscapes in Germany (Frank et al. 2013). "Land cover richness" and "patch density" within the direct surroundings of a cell are therefore likely to be appropriate proxies for the change in modelled landscape aesthetic capacity at the cell level due to configuration. 
We found no or only very weak correlation between changes in modelled ES capacity and the tested landscape metrics for the other ESs. Previous research showed that landscape metrics could be used to account for the effect of changing landscape structure on ES supply after land cover change (Frank et al. 2012). Other landscape metrics, not tested here, could possibly explain some of the variation in the difference between the composition and configuration model. Nonetheless, the fact that sediment retention and flood control are not correlated to any of the landscape metrics tested and the distance to stream was surprising. In the analysis we compared configuration effects at cell level in very different types of watersheds, both in size and in landscape composition, because we were interested in the use of landscape metrics for mapping ES at large spatial scales. For landscape aesthetics we did partly control for differences in landscape composition by assigning different landscape preferences scores depending on the dominant land cover type. We did not test whether landscape metrics could better explain the configuration effect at the cell level within a single watershed or for similar landscape compositions. However, previous research on the correlation between landscape metrics and sediment retention showed that the results were dependent on the land cover map used (Uuemaa et al. 2005) highlighting that caution should be applied in using landscape metrics to account for configuration effects. Alternatively, to capture the complex and variable effect of configuration on these ESs we suggest to map ES capacity using spatially explicit modelling frameworks that account for configuration (e.g. Nelson et al. 2009; Jackson et al. 2013).

\section{Mapping approach}

The ES models in this paper have not been developed for the purpose of most accurately mapping ES capacity, but rather to allow for the distillation of a configuration effect. We next discuss our mapping approach with respect to the capacity of distilling the configuration effect.

Large outliers were observed for the flood control and sediment retention model at the cell scale (see supplementary material 1). These outliers may be explained by two factors. First, the sediment retention model has been calibrated at the watershed scale, meaning that possible errors at the cell scale have not been checked. Second, we accounted for spatial pattern on flood control using flow accumulation. Although flow accumulation has been used by previous researchers (Chan et al. 2006) a more detailed hydrological model might render different results. However, we aimed to rely on existing techniques for mapping ESs and therefore applied flow accumulation. InVEST, a commonly-used tool to map ESs across larger scales, only accounts for the land cover capacity to retain incoming precipitation and does not account for the spatial configuration of the watershed by accounting for water input from upstream sites (Sharp et al. 2015). Third, neither the flood control model nor the sediment retention model accounts for saturation. This is a common issue in ES models (Nelson et al. 2009), but some modelling tools do account for the effect of soil saturation on water holding capacity and consequently on flood control capacity (e.g. Laterra et al. 2012; Jackson et al. 2013). The most recent version of the InVEST model for fresh water provisioning now also accounts for water holding capacity (Sharp et al. 2015). Incorporating saturation in ES models is important for mapping ES capacity influenced by configuration. The ES capacity at a site does not only depend on the characteristics of the cell but also on the input of either water or sediment from upstream sites. Not accounting for saturation may only result in a possible overestimation of ES capacity and is unlikely to change our finding that accounting for configuration predominantly leads to a reduction in mapped ES capacity per cell.

A limitation of our mapping approach is that the configuration models did not account for linear elements, which might result in an underestimation of the effect of configuration to ES capacity. Based on the literature review, linear elements affect ES capacity of flood control, pollination and nutrient and sediment retention. Maps of linear elements across scales are being developed using observation data or processing high resolution imagery data (e.g. Aksoy et al. 2010; van der Zanden et al. 2013). At the European scale linear elements have been incorporated in the assessment of soil erosion (Panagos et al. 2015) and pollination (Schulp et al. 2014b). Although linear elements only covered less than $5 \%$ of the agricultural area, their presence increased the visitation probability of pollinators by $5-20 \%$ (Schulp et al. 2014b). Linear elements were the sole source of pollination capacity in $12 \%$ of the agricultural areas 
(Schulp et al. 2014b). Both mapping approaches rely on the density and not the location of linear elements within an area. Readily available, full coverage data on the location of linear elements at a resolution of $1 \mathrm{~km}$ or smaller are however not yet available, despite efforts in this direction for the UK and Scotland (Barr and Gillespie 2000; Brown et al. 2014). Riparian habitats are another example of important landscape features capable of providing multiple ESs (Jones et al. 2010). The area of riparian forest is suggested as main indicator to map ES capacity for nutrient retention at the European scale (Maes et al. 2016). For the UK, the combination of land cover data at 25-m resolution with flow accumulation maps provides opportunities for the assessment of ESs in riparian zones and the impact of management and land cover change in riparian zones on future ES supply (Jones et al. 2010).

Implications for landscape management

Is landscape heterogeneity good? An important question to assess the promises of multifunctional landscapes is whether there is a uniform response of ESs to configuration (Macfadyen et al. 2012; Jones et al. 2013). Our results suggest a non-uniform response of ESs to configuration. First of all, based on the results of our review not all ESs have a clear relation to configuration and for those ESs that are affected by configuration, different aspects of configuration affect the ESs. The effect of configuration on ES capacity is thus dependent on the ES under study. Landscape configuration and heterogeneity are believed to be capable of alleviating trade-offs between ESs. Our results suggest that configuration acts in different ways on different ES and is thus likely to introduce new trade-offs between ESs. Effects of landscape configuration on single and multiple ESs will likely depend on the location, the composition and configuration of the landscape, the set of ES studied and the level of aggregation in ES assessment. Second, we also highlighted non-uniform responses in the effect of configuration on mapping ES capacity at the cell and watershed scale (Mitchell et al. 2015a). The total ES capacity at the watershed scale can be only slightly affected by configuration, but the locations with high ES capacity can change strongly after accounting for configuration. Management interested in maintaining locations of high ES supply should therefore account for configuration to effectively identify priority areas.

In our models we looked at the effect of configuration on single ESs and did not look at the effect of configuration on the capacity of multiple ESs. Landscape heterogeneity is not only expected to affect the level and location of ES capacity, but also the interactions between ESs (Bennett et al. 2009). In our literature review we did encounter studies on the relation between landscape configuration and the capacity of multiple ESs, but in line with findings from a previous review (Mitchell et al. 2013), none of the studies looked at interactions between multiple ESs. In ES mapping studies, multifunctional landscapes or ESs hotspots are often identified by combining individual ES maps for an area (e.g. Qiu and Turner 2013). Combining individual ES maps cannot be used as a way to reveal possible relations between configuration and landscape heterogeneity when interactions between ESs are not accounted for. Future empirical research on multifunctional landscapes should focus on the interactions between ESs and the effect of configuration on these interactions. Importantly, interactions between two ESs can be affected by landscape configuration, even when the ES capacity of the individual ESs is not affected by configuration. Landscape management for multifunctional landscapes should account for landscape configuration on ES supply as well as on the interactions between ESs.

Our results also provide relevant input for landscape management aimed at optimizing ESs. It has been argued that ES management can use landscape structure to enhance ES capacity (Jones et al. 2013; Turner et al. 2013). Our results provide tangible evidence that tools for managing ESs in landscapes should account for landscape configuration both in assessments of ES capacity given current land use, and in the assessment of impacts of land cover change (Lautenbach et al. 2011). Care should however be taken by translating findings from ES mapping studies to landscape management, especially when accounting for configuration. One reason is that recommendations based on mapping studies using coarse land cover maps, such as CORINE, are likely to only have limited use in explaining patterns of biodiversity and ESs for landscape management (Gimona et al. 2009). A second important aspect is that not only ES capacity but also ES demand is likely affected by landscape 
configuration. Studies on aesthetics and recreation often account for the landscape configuration in demand parameters such as accessibility (Guo et al. 2001; Chan et al. 2006; Chen et al. 2009; Larondelle and Haase 2013; Nahuelhual et al. 2013) or visitation rates (Wood et al. 2013). Other research has more strongly focused on the effects of landscape configuration on ES flows arguing that ES flows are more strongly impacted than ES capacity (Mitchell et al. $2015 \mathrm{a}, \mathrm{b})$. The fact that landscape configuration will affect ES capacity, ES demand and ES flows of multiple ESs simultaneously provides both opportunities and challenges for optimizing ESs through landscape management. Nonetheless, accounting for configuration can help protect ES capacity through identification of priority areas, and can help optimize ES capacity in landscapes through spatially explicit land management. The large differences between the composition and configuration model at the cell scale, but the smaller differences in ES capacity at the watershed scale, suggest that there is room for optimizing ES capacity by explicitly accounting for configuration in landscape management.

Acknowledgments We thank Sven Lautenbach for the access granted to a database constructed for a meta-analysis on ES studies and Nynke Schulp for fruitful discussions on the pollination model. Furthermore, we thank the anonymous reviewers for their thoughtful comments on a previous version of the manuscript which greatly improved the work. This work was financially supported by the European Union Seventh Framework Programme (FP7/2007-2013) under Grant Agreement No. 308393 "OPERAs". The authors with James Hutton Institute affiliation acknowledge the financial support of RESAS (Scottish Government). The authors declare that they have no conflict of interest.

Open Access This article is distributed under the terms of the Creative Commons Attribution 4.0 International License (http:// creativecommons.org/licenses/by/4.0/), which permits unrestricted use, distribution, and reproduction in any medium, provided you give appropriate credit to the original author(s) and the source, provide a link to the Creative Commons license, and indicate if changes were made.

\section{References}

Abson DJ, Fraser ED, Benton TG (2013) Landscape diversity and the resilience of agricultural returns: a portfolio analysis of land-use patterns and economic returns from lowland agriculture. Agric Food Secur 2:1-15. doi:10.1186/ 2048-7010-2-2
Acreman M, Holden J (2013) How wetlands affect floods. Wetlands 33:773-786. doi:10.1007/s13157-013-0473-2

Aksoy S, Akcay HG, Wassenaar T (2010) Automatic mapping of linear woody vegetation features in agricultural landscapes using very high resolution imagery. IEEE Trans Geosci Remote Sens. doi:10.1109/TGRS.2009.2027702

Alcamo J, van Vuuren D, Ringler C, Cramer W, Masui T, Alder J, Schulze K (2005) Changes in nature's balance sheet: model-based estimates of future worldwide ecosystem services. Ecol Soc 10(2):19

Anderson H, Futter M, Oliver I, Redshaw J, Harper A (2010) Trends in Scottish river water quality. Scottish Environment Protection Agency, Stirling

Andersson GKS, Birkhofer K, Rundlöf M, Smith HG (2013) Landscape heterogeneity and farming practice alter the species composition and taxonomic breadth of pollinator communities. Basic Appl Ecol 14:540-546. doi:10.1016/j. baae.2013.08.003

Aspinall R, Green D, Spray C, Shimmield T, Wilson J (2011) Status and changes in the UK ecosystems and their services to society: Scotland. UK National Ecosystem Assessment: Technical Report, pp 895-978

Bailey S, Requier F, Nusillard B, Robert SPM, Potts SG, Bouget C (2014) Distance from forest edge affects bee pollinators in oilseed rape fields. Ecol Evol 4:370-380. doi:10.1002/ ece 3.924

Balvanera P, Pfisterer AB, Buchmann N, He JS, Nakashizuka T, Raffaelli D, Schmid B (2006) Quantifying the evidence for biodiversity effects on ecosystem functioning and services. Ecol Lett 9:1146-1156. doi:10.1111/j.1461-0248.2006. 00963.x

Balvanera P, Siddique I, Dee L, Paquette A, Isbell F, Gonzalez A, Byrnes J, O’Connor MI, Hungate BA, Griffin JN (2014) Linking biodiversity and ecosystem services: current uncertainties and the necessary next steps. Bioscience 64:49-57. doi:10.1093/biosci/bit003

Barr CJ, Gillespie MK (2000) Estimating hedgerow length and pattern characteristics in Great Britain using Countryside Survey data. J Environ Manag 60:23-32. doi:10.1006/ jema.2000.0359

Bartley R, Roth CH, Ludwig J, McJannet D, Liedloff A, Corfield J, Hawdon A, Abbott B (2006) Runoff and erosion from Australia's tropical semi-arid rangelands: influence of ground cover for differing space and time scales. Hydrol Process 20:3317-3333. doi:10.1002/hyp.6334

Bateni F, Fakheran S, Soffianian A (2013) Assessment of land cover changes \& water quality changes in the Zayandehroud River Basin between 1997-2008. Environ Monit Assess 185:10511-10519. doi:10.1007/s10661-0133348-3

Bennett EM, Peterson GD, Gordon LJ (2009) Understanding relationships among multiple ecosystem services. Ecol Lett 12:1394-1404. doi:10.1111/j.1461-0248.2009.01387.x

Bianchi FJJA, Booij CJH, Tscharntke T (2006) Sustainable pest regulation in agricultural landscapes: a review on landscape composition, biodiversity and natural pest control. Proc Biol Sci 273:1715-1727. doi:10.1098/rspb.2006.3530

Bianchi FJJA, Schellhorn NA, Buckley YM, Possingham HP (2010) Spatial variability in ecosystem services: simple rules for predator-mediated pest suppression. Ecol Appl 20:2322-2333 
Bodin O, Tengö M, Norman A, Lundberg J, Elmqvist T (2006) The value of small size: loss of forest patches and ecological thresholds in southern Madagascar. Ecol Appl 16:440-451

Borin M, Passoni M, Thiene M, Tempesta T (2010) Multiple functions of buffer strips in farming areas. Eur J Agron 32:103-111. doi:10.1016/j.eja.2009.05.003

Braskerud BC (2002) Factors affecting nitrogen retention in small constructed wetlands treating agricultural non-point source pollution. Ecol Eng 18:351-370. doi:10.1016/ S0925-8574(01)00099-4

Brown MJ, Bunce RGH, Carey PD, Chandler K, Crow A, Maskell LC, Norton LR, Scott RJ, Scott WA, Smart SM, Stuart RC, Wood, CM, Wright SM (2014) Countryside survey 2007 mapped estimates of linear feature lengths in Great Britain. NERC Environmental Information Data Centre. http://nora.nerc.ac.uk/508500/

Bu C, Cai Q, Ng S, Chau K, Ding S (2008) Effects of hedgerows on sediment erosion in Three Gorges Dam Area, China. Int J Sediment Res 23:119-129

Burkhard B, Kandziora M, Hou Y, Müller F (2014) Ecosystem service potentials, flows and demands-concepts for spatial localisation, indication and quantification. Landsc Online 34:1-32. doi:10.3097/LO.201434

Burkhard B, Kroll F, Müller F (2009) Landscapes' capacities to provide ecosystem services-a concept for land-cover based assessments. Landsc Online. doi:10.3097/LO. 200915

Burkhard B, Kroll F, Nedkov S, Müller F (2012) Mapping ecosystem service supply, demand and budgets. Ecol Indic 21:17-29. doi:10.1016/j.ecolind.2011.06.019

Calder IR (2007) Forests and water-ensuring forest benefits outweigh water costs. For Ecol Manag 251:110-120. doi:10.1016/j.foreco.2007.06.015

Cardinale BJ, Duffy JE, Gonzalez A, Hooper DU, Perrings C, Venail P, Narwani A, Mace GM, Tilman D, Wardle DA, Kinzig AP (2012) Biodiversity loss and its impact on humanity. Nature 486:59-67. doi:10.1038/nature11148

Carroll ZL, Bird SB, Emmett BA, Reynolds B, Sinclair FL (2004) Can tree shelterbelts on agricultural land reduce flood risk? Soil Use Manag 20:357-359. doi:10.1079/ SUM2004266

Casado-Arzuaga I, Onaindia M, Madariaga I, Verburg PH (2013) Mapping recreation and aesthetic value of ecosystems in the Bilbao Metropolitan Greenbelt (northern Spain) to support landscape planning. Landscape Ecol. doi:10. 1007/s10980-013-9945-2

Castelle AJ, Johnson AW, Connoly C (1994) Wetland and Stream buffer size requirements-a review. J Environ Qual 23:878-882

CEH (2011) UK land cover map 2007

Chan KM, Shaw MR, Cameron DR, Underwood EC, Daily GC (2006) Conservation planning for ecosystem services. PLoS Biol 4:e379. doi:10.1371/journal.pbio.0040379

Chaplin-Kramer R, Kremen C (2012) Pest control experiments show benefits of complexity at landscape and local scales. Ecol Appl 22:1936-1948

Chaplin-Kramer R, O’Rourke ME, Blitzer EJ, Kremen C (2011) A meta-analysis of crop pest and natural enemy response to landscape complexity. Ecol Lett 14:922-932. doi:10.1111/ j.1461-0248.2011.01642.x
Chen N, Li H, Wang L (2009) A GIS-based approach for mapping direct use value of ecosystem services at a county scale: management implications. Ecol Econ 68:2768-2776. doi:10.1016/j.ecolecon.2008.12.001

D’Acunto L, Semmartin M, Ghersa CM (2014) Uncropped field margins to mitigate soil carbon losses in agricultural landscapes. Agric Ecosyst Environ 183:60-68. doi:10. 1016/j.agee.2013.10.022

de la Fuente de Val G, Atauri JA, de Lucio JV (2006) Relationship between landscape visual attributes and spatial pattern indices: a test study in Mediterranean-climate landscapes. Landsc Urban Plan 77:393-407. doi:10.1016/j. landurbplan.2005.05.003

de Paula M, Costa C, Tabarelli M (2011) Carbon storage in a fragmented landscape of Atlantic forest: the role played by edge-affected habitats and emergent trees. Trop Conserv Sci 4:349-358

Deguines N, Jono C, Baude M, Henry M, Julliard R, Fontaine C (2014) Large-scale trade-off between agricultural intensification and crop pollination services. Front Ecol Environ 12:212-217. doi:10.1890/130054

Dramstad WE, Tveit MS, Fjellstad WJ, Fry GLA (2006) Relationships between visual landscape preferences and mapbased indicators of landscape structure. Landsc Urban Plan 78:465-474. doi:10.1016/j.landurbplan.2005.12.006

Eigenbrod F, Armsworth PR, Anderson BJ, Heinemeyer A, Gillings S, Roy DB, Thomas CD, Gaston KJ (2010) The impact of proxy-based methods on mapping the distribution of ecosystem services. J Appl Ecol 47:377-385. doi:10.1111/j.1365-2664.2010.01777.x

Fahrig L, Baudry J, Brotons L, Burel FG, Crist TO, Fuller RJ, Sirami C, Siriwardena GM, Martin JL (2011) Functional landscape heterogeneity and animal biodiversity in agricultural landscapes. Ecol Lett 14:101-112. doi:10.1111/j. 1461-0248.2010.01559.x

Fahrig L, Nuttle WK (2005) Population ecology in spatially heterogeneous environments. In: Lovett GM, Turner MG, Jones GG, Weathers KC (eds) Ecosystem function in heterogeneous landscapes. Springer, New York, pp 95118

Falloon P, Powlson D, Smith P (2004) Managing field margins for biodiversity and carbon sequestration: a Great Britain case study. Soil Use Manag 20:240-247. doi:10.1079/ SUM2004236

Foereid B, Bro R, Mogensen VO, Porter JR (2002) Effects of windbreak strips of willow coppice-modelling and field experiment on barley in Denmark. Agric Ecosyst Environ 93:25-32. doi:10.1016/S0167-8809(02)00007-5

Foley JA, DeFries R, Asner GP, Barford C, Bonan G, Carpenter SR, Chapin FS, Coe MT, Daily GC, Gibbs HK, Helkowski JH (2005) Global consequences of land use. Science 309:570-574. doi:10.1126/science.1111772

Follain S, Walter C, Legout A, Lemercier B, Dutin G (2007) Induced effects of hedgerow networks on soil organic carbon storage within an agricultural landscape. Geoderma 142:80-95. doi:10.1016/j.geoderma.2007.08.002

Forman RTT (1995) Some general principles of landscape and regional ecology. Landscape Ecol 10:133-142. doi:10. 1007/BF00133027

Frank S, Fürst C, Koschke L, Makeschin F (2012) A contribution towards a transfer of the ecosystem service concept to 
landscape planning using landscape metrics. Ecol Indic 21:30-38. doi:10.1016/j.ecolind.2011.04.027

Frank S, Fürst C, Koschke L, Witt A, Makeschin F (2013) Assessment of landscape aesthetics-validation of a landscape metrics-based assessment by visual estimation of the scenic beauty. Ecol Indic 32:222-231. doi:10.1016/j. ecolind.2013.03.026

Gergel SE (2005) Spatial and non-spatial factors: when do they affect landscape indicators of watershed loading? Landsc Ecol 20:177-189. doi:10.1007/s10980-004-2263-y

Gimona A, Messager P, Occhi M (2009) CORINE-based landscape indices weakly correlate with plant species richness in a northern European landscape transect. Landscape Ecol 24:53-64. doi:10.1007/s10980-008-9279-7

Goodrich DC, Guertin DP, Burns IS, Nearing MA, Stone JJ, Wei H, Heilman P, Hernandez M, Spaeth K, Pierson F, Paige GB (2011) AGWA: the automated geospatial watershed assessment tool to inform rangeland management. BioOne 33:41-47. doi:10.2111/1551-501X-33.4.41

Guo Z, Xiao X, Gan Y, Zheng Y (2001) Ecosystem functions, services and their values - a case study in Xingshan County of China. Ecol Econ 38:141-154. doi:10.1016/ S0921-8009(01)00154-9

Harrison PA, Berry PM, Simpson G, Haslett JR, Blicharska M, Bucur M, Dunford R, Egoh B, Garcia-Llorente M, Geamănă N, Geertsema W (2014) Linkages between biodiversity attributes and ecosystem services: a systematic review. Ecosyst Serv 9:191-203. doi:10.1016/j.ecoser. 2014.05.006

Heathwaite AL, Griffiths P, Parkinson RJ (1998) Nitrogen and phosphorus in runoff from grassland with buffer strips following application of fertilizers and manures. Soil Use Manag 14:142-148. doi:10.1111/j.1475-2743.1998. tb00140.x

Isaacs R, Kirk AK (2010) Pollination services provided to small and large highbush blueberry fields by wild and managed bees. J Appl Ecol 47:841-849. doi:10.1111/j.1365-2664. 2010.01823.x

Jackson B, Pagella T, Sinclair F, Orellana B, Henshaw A, Reynolds B, Mcintyre N, Wheater H, Eycott A (2013) Polyscape: a GIS mapping framework providing efficient and spatially explicit landscape-scale valuation of multiple ecosystem services. Landsc Urban Plan 112:74-88. doi:10. 1016/j.landurbplan.2012.12.014

Johnson L, Richards C, Host G, Arthur J (1997) Landscape influences on water chemistry in Midwestern stream ecosystems. Freshw Biol 37:193-208. doi:10.1046/j.13652427.1997.d01-539.x

Jones KB, Slonecker ET, Wade TG, Hamann S (2010) Riparian habitat changes across the continental United States (1972-2003) and potential implications for sustaining ecosystem services. Landscape Ecol 25:1261-1275. doi:10.1007/s10980-010-9510-1

Jones KB, Zurlini G, Kienast F, Petrosillo I, Edwards T, Wade TG, Li BL, Zaccarelli N (2013) Informing landscape planning and design for sustaining ecosystem services from existing spatial patterns and knowledge. Landscape Ecol 28:1175-1192. doi:10.1007/s10980-012-9794-4

Kane MJ, Emerson JW, Weston S (2013) Scalable strategies for computing with massive data. J Stat Softw 55:1-19
Kareiva P, Tallis H, Ricketts TH, Daily GC, Polasky S (eds) (2011) Natural capital: theory and practice of mapping ecosystem services. Oxford University Press Inc., New York

Kells AR, Goulson D (2003) Preferred nesting sites of bumblebee queens (Hymenoptera: apidae) in agroecosystems in the UK. Biol Conserv 109:165-174. doi:10.1016/S00063207(02)00131-3

Kennedy CM, Lonsdorf E, Neel MC, Williams NM, Ricketts TH, Winfree R, Bommarco R, Brittain C, Burley AL, Cariveau D, Carvalheiro LG, Chacoff NP, Cunningham SA, Danforth BN, Dudenhöffer J, Elle E, Gaines HR, Garibaldi LA, Gratton C, Holzschuh A, Isaacs R, Javorek SK, Jha S, Klein AM, Krewenka K, Mandelik Y, Mayfield MM, Morandin L, Neame LA, Otieno M, Park M, Potts SG, Rundlöf M, Saez A, Steffan-Dewenter I, Taki H, Viana BF, Westphal C, Wilson JK, Greenleaf SS, Kremen C (2013) A global quantitative synthesis of local and landscape effects on wild bee pollinators in agroecosystems. Ecol Lett 16:584-599. doi:10.1111/ele.12082

Kienast F, Degenhardt B, Weilenmann B, Wäger Y, Buchecker M (2012) GIS-assisted mapping of landscape suitability for nearby recreation. Landsc Urban Plan 105:385-399. doi:10.1016/j.landurbplan.2012.01.015

Klein Goldewijk K (2001) Estimating global land use change over the past 300 years: the HYDE database. Global Biogeochem Cycles 15:417-433. doi:10.1029/1999GB001232

Kremen C, Williams NM, Bugg RL, Fay JP, Thorp RW (2004) The area requirements of an ecosystem service: crop pollination by native bee communities in California. Ecol Lett 7:1109-1119. doi:10.1111/j.1461-0248.2004.00662.x

Larondelle N, Haase D (2013) Urban ecosystem services assessment along a rural-urban gradient: a cross-analysis of European cities. Ecol Indic 29:179-190. doi:10.1016/j. ecolind.2012.12.022

Laterra P, Orúe ME, Booman GC (2012) Spatial complexity and ecosystem services in rural landscapes. Agric Ecosyst Environ 154:56-67. doi:10.1016/j.agee.2011.05.013

Laurance WF, Camargo JL, Luizão RC, Laurance SG, Pimm SL, Bruna EM, Stouffer PC, Williamson GB, BenítezMalvido J, Vasconcelos HL, Van Houtan KS (2011) The fate of Amazonian forest fragments: a 32-year investigation. Biol Conserv 144:56-67

Lautenbach S, Kugel C, Lausch A, Seppelt R (2011) Analysis of historic changes in regional ecosystem service provisioning using land use data. Ecol Indic 11:676-687. doi:10. 1016/j.ecolind.2010.09.007

Lautenbach S, Mupepele AC, Dormann CF, Lee H, Schmidt S, Scholte SS, Seppelt R, van Teeffelen AJ, Verhagen W, Volk M (2015) Blind spots in ecosystem services research and implementation. bioRxiv. doi:10.1101/033498

Lee S-W, Hwang S-J, Lee S-B, Hwang H-S, Sung H-C (2009) Landscape ecological approach to the relationships of land use patterns in watersheds to water quality characteristics. Landsc Urban Plan 92:80-89. doi:10.1016/j.landurbplan. 2009.02.008

Lemessa D, Hylander K, Hambäck P (2013) Composition of crops and land-use types in relation to crop raiding pattern at different distances from forests. Agric Ecosyst Environ 167:71-78. doi:10.1016/j.agee.2012.12.014 
Lenka NK, Dass A, Sudhishri S, Patnaik US (2012) Soil carbon sequestration and erosion control potential of hedgerows and grass filter strips in sloping agricultural lands of eastern India. Agric Ecosyst Environ 158:31-40. doi:10.1016/j. agee.2012.05.017

Liu W, Zhang Q, Liu G (2012) Influences of watershed landscape composition and configuration on lake-water quality in the Yangtze River basin of China. Hydrol Process 26:570-578. doi:10.1002/hyp.8157

Lonsdorf E, Ricketts TH, Kremen C, Winfree R, Greenleaf S, Williams N (2011) Crop pollination services. In: Kareiva $\mathrm{P}$, Tallis H, Ricketts TH et al (eds) Natural capital: theory and practice of mapping ecosystem services. Oxford University Press Inc., New York, p 17

Lovett GM, Jones CG, Turner MG, Weathers KC (eds) (2005) Ecosystem function in heterogeneous landscapes. Springer-Verlag, New York

Ludwig JA, Bartley R, Hawdon AA, Abbott BN, McJannet D (2007) Patch configuration non-linearly affects sediment loss across scales in a grazed catchment in North-east Australia. Ecosystems 10:839-845. doi:10.1007/s10021007-9061-8

Lull HW, Reinhart KG (1972) Forests and floods in the eastern United States. USDA forest service research paper no. NE226. Northeastern Forest Experiment Station, Upper Darby, PA

Mace GM, Norris K, Fitter AH (2012) Biodiversity and ecosystem services: a multilayered relationship. Trends Ecol Evol 27:19-26. doi:10.1016/j.tree.2011.08.006

Macfadyen S, Cunningham SA, Costamagna AC, Schellhorn NA (2012) Managing ecosystem services and biodiversity conservation in agricultural landscapes: are the solutions the same? J Appl Ecol 49:690-694. doi:10.1111/j.13652664.2012.02132.x

Macfadyen S, Muller W (2013) Edges in agricultural landscapes: species interactions and movement of natural enemies. PLoS One 8:e59659. doi:10.1371/journal.pone. 0059659

Maes J, Liquete C, Teller A, Erhard M (2016) An indicator framework for assessing ecosystem services in support of the EU Biodiversity Strategy to 2020 An indicator framework for assessing ecosystem services in support. Ecosyst Serv 17:14-23. doi:10.1016/j.ecoser.2015.10. 023

Marshall MR, Francis OJ, Frogbrook ZL, Jackson BM, McIntyre N, Reynolds B, Solloway I, Wheater HS, Chell J (2009) The impact of upland land management on flooding: results from an improved pasture hillslope. Hydrol Process 475:464-475. doi:10.1002/hyp.7157

Martínez-Harms MJ, Balvanera P (2012) Methods for mapping ecosystem service supply: a review. Int J Biodivers Sci Ecosyst Serv Manag 8:1-9. doi:10.1080/21513732.2012. 663792

May L, Place C (2005) A gis-based model of soil erosion and transport. Freshw Forum 23:48-61

Mayor ÁG, Bautista S, Bellot J (2011) Scale-dependent variation in runoff and sediment yield in a semiarid Mediterranean catchment. J Hydrol 397:128-135. doi:10.1016/j. jhydrol.2010.11.039

MEA (2005) Ecosystems and human well-being: synthesis. Island Press, Washington, DC
Mitchell MGE, Bennett EM, Gonzalez A (2013) Linking landscape connectivity and ecosystem service provision: current knowledge and research gaps. Ecosystems 16:894-908. doi:10.1007/s 10021-013-9647-2

Mitchell MGE, Bennett EM, Gonzalez A (2014) Agricultural landscape structure affects arthropod diversity and arthropod-derived ecosystem services. Agric Ecosyst Environ 192:144-151. doi:10.1016/j.agee.2014.04.015

Mitchell MGE, Bennett EM, Gonzalez A (2015a) Strong and nonlinear effects of fragmentation on ecosystem service provision at multiple scales. Environ Res Lett. doi:10. 1088/1748-9326/10/9/094014

Mitchell MG, Suarez-Castro AF, Martinez-Harms M, Maron M, McAlpine C, Gaston KJ, Johansen K, Rhodes JR (2015b) Reframing landscape fragmentation's effects on ecosystem services. Trends Ecol Evol 30:190-198. doi:10.1016/j.tree. 2015.01.011

Monfreda C, Ramankutty N, Foley JA (2008) Farming the planet: 2. Geographic distribution of crop areas, yields, physiological types, and net primary production in the year 2000 . Global Biogeochem Cycles. doi: 10.1029/2007GB002947

Morandin LA, Kremen C (2013) Hedgerow restoration promotes pollinator populations and exports native bees to adjacent fields. Ecol Appl 23:829-839. doi:10.1890/121051.1

Morandin LA, Long RF, Kremen C (2014) Hedgerows enhance beneficial insects on adjacent tomato fields in an intensive agricultural landscape. Agric Ecosyst Environ 189:164170. doi:10.1016/j.agee.2014.03.030

Nahuelhual L, Carmona A, Lozada P, Jaramillo A, Aguayo M (2013) Mapping recreation and ecotourism as a cultural ecosystem service: an application at the local level in Southern Chile. Appl Geogr 40:71-82. doi:10.1016/j.apgeog. 2012.12.004

Nelson E, Mendoza G, Regetz J, Polasky S, Tallis H, Cameron D, Chan KM, Daily GC, Goldstein J, Kareiva PM, Lonsdorf E (2009) Modeling multiple ecosystem services, biodiversity conservation, commodity production, and tradeoffs at landscape scales. Front Ecol Environ 7:4-11. doi:10.1890/080023

Panagos P, Borrelli P, Meusburger K, van der Zanden EH, Poesen J, Alewell C (2015) Modelling the effect of support practices (P-factor) on the reduction of soil erosion by water at European scale. Environ Sci Policy 51:23-34. doi:10.1016/j.envsci.2015.03.012

Perović DJ, Gurr GM, Raman A, Nicol HI (2010) Effect of landscape composition and arrangement on biological control agents in a simplified agricultural system: a costdistance approach. Biol Control 52:263-270. doi:10.1016/ j.biocontrol.2009.09.014

Persson AS, Olsson O, Rundlöf M, Smith HG (2010) Land use intensity and landscape complexity-Analysis of landscape characteristics in an agricultural region in Southern Sweden. Agric Ecosyst Environ 136:169-176. doi:10. 1016/j.agee.2009.12.018

Pisani TL, Letourneau DK, Shennan C, Gareau TLP (2013) Relative densities of natural enemy and pest insects within California hedgerows. Environ Entomol 42:688-702

Plummer ML (2009) Assessing benefit transfer for the valuation of ecosystem services. Front Ecol Environ 7:38-45. doi:10. $1890 / 080091$ 
Pollard KA, Holland JM (2006) Arthropods within the woody element of hedgerows and their distribution pattern. Agric For Entomol 8:203-211. doi:10.1111/j.1461-9563.2006. 00297.x

Potts SG, Vulliamy B, Dafni A, Ne'eman G, Willmer P (2003) Linking bees and flowers: how do floral communities structure pollinator communities? Ecology 84:2628-2642. doi:10.1890/02-0136

Poveda K, Martínez E, Kersch-Becker MF, Bonilla MA, Tscharntke T (2012) Landscape simplification and altitude affect biodiversity, herbivory and Andean potato yield. J Appl Ecol 49:513-522. doi:10.1111/j.1365-2664.2012. 02120.x

Power AG (2010) Ecosystem services and agriculture: tradeoffs and synergies. Philos Trans R Soc Lond B 365:2959-2971. doi:10.1098/rstb.2010.0143

Qiu J, Turner MG (2013) Spatial interactions among ecosystem services in an urbanizing agricultural watershed. Proc Natl Acad Sci USA 110:12149-12154. doi:10.1073/pnas. 1310539110

R Core Team (2013) A language and environment for statistical computing. R Foundation for Statistical Computing, Vienna, Austria

Renard K, Foster G, Weesies G, Porter JP (1997) Predicting soil erosion by water: a guide to conservation planning with the Revised Universal Soil Loss Equation (RUSLE). United States Department of Agriculture

Ricketts TH, Regetz J, Steffan-Dewenter I, Cunningham SA, Kremen C, Bogdanski A, Gemmill-Herren B, Greenleaf SS, Klein AM, Mayfield MM, Morandin LA (2008) Landscape effects on crop pollination services: are there general patterns? Ecol Lett 11:499-515. doi:10.1111/j. 1461-0248.2088.01157.x

Rodríguez JP, Beard TD, Bennett EM, Cumming GS, Cork SJ, Agard J, Dobson AP, Peterson GD (2006) Trade-offs across space, time and ecosystem services. Ecol Soc 11:28. doi: $10.2307 / 2390206$

Rollin O, Bretagnolle V, Decourtye A, Aptel J, Michel N, Vaissière BE, Henry M (2013) Differences of floral resource use between honey bees and wild bees in an intensive farming system. Agric Ecosyst Environ 179:78-86. doi:10.1016/j.agee.2013.07.007

Roschewitz I, Hücker M, Tscharntke T, Thies C (2005a) The influence of landscape context and farming practices on parasitism of cereal aphids. Agric Ecosyst Environ 108:218-227. doi:10.1016/j.agee.2005.02.005

Roschewitz I, Thies C, Tscharntke T (2005b) Are landscape complexity and farm specialisation related to land-use intensity of annual crop fields? Agric Ecosyst Environ 105:87-99. doi:10.1016/j.agee.2004.05.010

Rusch A, Valantin-Morison M, Roger-Estrade J, Sarthou JP (2012) Using landscape indicators to predict high pest infestations and successful natural pest control at the regional scale. Landsc Urban Plan 105:62-73. doi:10. 1016/j.landurbplan.2011.11.021

Schindler S, Sebesvari Z, Damm C, Euller K, Mauerhofer V, Schneidergruber A, Biró M, Essl F, Kanka R, Lauwaars SG, Schulz-Zunkel C (2014) Multifunctionality of floodplain landscapes: Relating management options to ecosystem services. Landscape Ecol 29:229-244. doi:10. 1007/s10980-014-9989-y
Schulp CJ, Burkhard B, Maes J, Van Vliet J, Verburg PH (2014a) Uncertainties in ecosystem service maps: a comparison on the European scale. PLoS One 9:11. doi:10. 1371/journal.pone.0109643

Schulp CJE, Lautenbach S, Verburg PH (2014b) Quantifying and mapping ecosystem services: demand and supply of pollination in the European Union. Ecol Indic 36:131-141. doi:10.1016/j.ecolind.2013.07.014

Seppelt R, Dormann CF, Eppink FV, Lautenbach S, Schmidt S (2011) A quantitative review of ecosystem service studies: approaches, shortcomings and the road ahead. J Appl Ecol 48:630-636. doi:10.1111/j.1365-2664.2010.01952.x

Sharp R, Chaplin-Kramer R, Wood S, Guerry A, Tallis H, Ricketts T (2015) InVEST user guide

Sherrouse BC, Clement JM, Semmens DJ (2011) A GIS application for assessing, mapping, and quantifying the social values of ecosystem services. Appl Geogr 31:748-760. doi:10.1016/j.apgeog.2010.08.002

Shi ZH, Ai L, Li X, Huang XD, Wu GL, Liao W (2013) Partial least-squares regression for linking land-cover patterns to soil erosion and sediment yield in watersheds. J Hydrol 498:165-176. doi:10.1016/j.jhydrol.2013.06.031

Sparkes DL, Jaggard KW, Ramsden SJ, Scott RK (1998) The effect of field margins on the yield of sugar beet and cereal crops. Ann Appl Biol 132:129-142. doi:10.1111/j.17447348.1998.tb05190.x

Sriwongsitanon N, Taesombat W (2011) Effects of land cover on runoff coefficient. J Hydrol 410:226-238. doi:10.1016/ j.jhydrol.2011.09.021

Stanley DA, Stout JC (2014) Pollinator sharing between massflowering oilseed rape and co-flowering wild plants: implications for wild plant pollination. Plant Ecol 215:315-325. doi:10.1007/s11258-014-0301-7

Stein A, Gerstner K, Kreft H (2014) Environmental heterogeneity as a universal driver of species richness across taxa, biomes and spatial scales. Ecol Lett 17:866-880. doi:10. 1111/ele.12277

Stoll S, Frenzel M, Burkhard B, Adamescu M, Augustaitis A, Baeßler C, Bonet FJ, Carranza ML, Cazacu C, Cosor GL, Díaz-Delgado R (2014) Assessment of ecosystem integrity and service gradients across Europe using the LTER Europe network. Ecol Modell. doi:10.1016/j.ecolmodel.2014. 06.019

Sude B, Nan W, Ji-Xi G, Chen Z, Jing G, Driss E (2011) New approach for evaluation of a watershed ecosystem service for avoiding reservoir sedimentation and its economic value: a case study from Ertan Reservoir in Yalong River, China. Appl Environ Soil Sci. doi:10.1155/2011/576947

Sun R, Chen L, Chen W, Ji Y (2013) Effect of land-use patterns on total nitrogen concentration in the upstream regions of the Haihe River Basin, China. Environ Manage 51:45-58. doi:10.1007/s00267-011-9764-7

Svensson B, Lagerlöf J, Svensson BG (2000) Habitat preferences of nest-seeking bumble bees (Hymenoptera: Apidae) in an agricultural landscape. Agric Ecosyst Environ 77:247-255. doi:10.1016/S0167-8809(99)00106-1

Thies C, Tscharntke T (1999) Landscape structure and biological control in agroecosystems. Science 285:893-895. doi:10.1126/science.285.5429.893

Tscharntke T, Bommarco R, Clough Y, Crist TO, Kleijn D, Rand TA, Tylianakis JM, Van Nouhuys S, Vidal S (2007) 
Conservation biological control and enemy diversity on a landscape scale. Biol Control 43:294-309. doi:10.1016/j. biocontrol.2007.08.006

Turner BL, Janetos AC, Verburg PH, Murray AT (2013) Land system architecture: using land systems to adapt and mitigate global environmental change. Glob Environ Chang 23:395-397. doi:10.1016/j.gloenvcha.2012.12.009

Uuemaa E, Roosaare J, Mander Ü (2005) Scale dependence of landscape metrics and their indicatory value for nutrient and organic matter losses from catchments. Ecol Indic 5:350-369. doi:10.1016/j.ecolind.2005.03.009

van der Zanden EH, Verburg PH, Mücher CA (2013) Modelling the spatial distribution of linear landscape elements in Europe. Ecol Indic 27:125-136. doi:10.1016/j.ecolind. 2012.12.002

van Zanten BT, Verburg PH, Koetse MJ, van Beukering PJH (2014) Preferences for European agrarian landscapes: a meta-analysis of case studies. Landsc Urban Plan 132:89-101. doi:10.1016/j.landurbplan.2014.08.012

Vollhardt IMG, Tscharntke T, Wäckers FL, Bianchi FJJA, Thies C (2008) Diversity of cereal aphid parasitoids in simple and complex landscapes. Agric Ecosyst Environ 126:289-292. doi:10.1016/j.agee.2008.01.024

von Freyberg J, Radny D, Gall HE, Schirmer M (2014) Implications of hydrologic connectivity between hillslopes and riparian zones on streamflow composition. J Contam Hydrol 169:62-74. doi:10.1016/j.jconhyd.2014.07.005

Wang XH, Yin CQ, Shan BQ (2005) The role of diversified landscape buffer structures for water quality improvement in an agricultural watershed, North China. Agric Ecosyst Environ 107:381-396. doi:10.1016/j.agee.2004.09.005

Wickham H (2007) Reshaping data with the reshape package. J Stat Softw 21:1-20. doi:10.1016/S0142-1123(99)00007-9
Wiens JA (2002) Riverine landscapes: taking landscape ecology into the water. Freshw Biol 47:501-515. doi:10.1046/j. 1365-2427.2002.00887.x

Williams A, Hedlund K (2013) Indicators of soil ecosystem services in conventional and organic arable fields along a gradient of landscape heterogeneity in southern Sweden. Appl Soil Ecol 65:1-7. doi:10.1016/j.apsoil.2012.12.019

Williams NM, Kremen C (2007) Resource distributions among habitats determine solitary bee offspring production in a mosaic landscape. Ecol Appl 17:910-921. doi:10.1890/060269

Winfree R, Aguilar R, Vázquez DP, LeBuhn G, Aizen LA (2009) A meta-analysis of bees' responses to anthropogenic disturbance. Ecology 90:2068-2076. doi:10.1890/ 08-1245.1

Wood SA, Guerry AD, Silver JM, Lacayo M (2013) Using social media to quantify nature-based tourism and recreation. Sci Rep 3:2976. doi:10.1038/srep02976

Yang M, Li X, Hu Y, He X (2012) Assessing effects of landscape pattern on sediment yield using sediment delivery distributed model and a landscape indicator. Ecol Indic 22:38-52. doi:10.1016/j.ecolind.2011.08.023

Ziter C, Bennett EM, Gonzalez A (2014) Temperate forest fragments maintain aboveground carbon stocks out to the forest edge despite changes in community composition. Oecologia 176:893-902. doi:10.1007/s00442-014-3061-0

Zulian G, Maes J, Paracchini M (2013) Linking land cover data and crop yields for mapping and assessment of pollination services in Europe. Land 2:472-492. doi:10.3390/ land 2030472 